\title{
ASPEK ERGONOMI PADA AKTIVITAS PENANGKAPAN IKAN DENGAN KAPAL PAYANG DI PALABUHANRATU-SUKABUMI
}

\author{
Ergonomic Aspect on Fishing Activity of Payang Boat in Palabuhanratu-Sukabumi
}

\author{
Oleh : \\ Deni Achmad Soeboer ${ }^{1^{*}}$, Mohammad Imron ${ }^{2}$, Budhi Hascaryo Iskandar ${ }^{2}$, \\ Muhammad Patria Laksono ${ }^{3}$ \\ ${ }^{1}$ Staf Pengajar Pascasarjana TPL-Dep PSP-FPIK-IPB \\ ${ }^{2}$ Staf Pengajar Departemen PSP-FPIK-IPB \\ ${ }^{3}$ Mahasiswa Program Studi Teknologi dan Manajemen Perikanan Tangkap \\ *Korespondensi: denisoeboer@gmail.com
}

\begin{abstract}
ABSTRAK
Ergonomi kapal sangat mempengaruhi kenyamanan kerja anak buah kapal (ABK). Aspek ergonomi kapal khususnya kapal penangkap ikan masih sedikit yang meneliti, sehingga belum ada aturan baku mengenai kaidah-kaidah ergonomi. Penelitian ini bertujuan untuk memberikan pengayaan IPTEKS pada bidang keselamatan kerja di atas kapal penangkapan ikan, menganalisa aspek ergonomi pada aktivitas penangkapan ikan di kapal payang. Hal ini dapat menjadi masukan bagi pemangku kepentingan seperti pemilik kapal, kapten kapal dan ABK, serta pemerintah yang terkait. Metode yang digunakan dalam penelitian ini adalah observasi langsung pada abyek penelitian dan di analisa menggunakan tabel Job Safety Analysis (JSA). Aktivitas di atas kapal payang dibagi menjadi beberapa kegiatan yaitu persiapan keluar dermaga, operasional penangkapan ikan meliputi setting dan hauling, pasca operasi penangkapan ikan dan istirahat. Analisis ergonomi kapal payang difokuskan kepada posisi tata letak barang dan nelayan di atas kapal. Berdasarkan hasil pengamatan dan wawancara dengan ABK kapal payang tentang kenyamanan kerja di atas kapal sudah merasa nyaman. Hal ini dikarenakan sudah terbiasa dan tidak mempunyai pilihan lain.
\end{abstract}

Kata kunci : ergonomis, JSA, kapal payang.

\begin{abstract}
Ergonomics is greatly affect for the comfort of working ship crew, Ergonomic aspects in particular a board fishing vessels are still a few who researched, so there is no fixed rule for the rules of ergonomics. This study was conducted to provide enrichment of science and technology in the field of safety on board fishing, analyse in aspects of ergonomics in fishing activity on payang board. It can be input for stakeholders such a ship owners, ship's captain and crew, as well as related to the government. The method used in this research is direct observation on subject research and analysis used the table Job Safety Analysis (JSA). Activities on payang board divided into several activities such as preparation out dock, fishing which contains of operational setting and hauling, post operative fishing and rest. Payang ergonomics analysis focused on the position of the ship layout and fishing goods on board. Based on the observation and interviews, the crew of payang ship feel comfortable. This caused by the crew had already accustomed and had no another choice.
\end{abstract}

Keywords : ergonimic, JSA, payang fishing boat. 


\section{PENDAHULUAN}

Ergonomic adalah ilmu yang mempelajari perilaku manusia dengan pekerjaan mereka. Secara singkat dapat dikatakan bahwa ergonomi adalah penyesuaian tugas pekerjaan dengan kondisi tubuh manusia untuk menurunkan stress yang akan dihadapi (Artayasa, 2010). Upaya yang dapat dilakukan antara lain berupa menyesuaikan ukuran tempat kerja dengan dimensi tubuh agar sesuai dengan kebutuhan tubuh manusia. Sebagian orang berpendapat bahwa kenyamanan kerja juga berpengaruh pada keselamatan kerja. Oleh karena itu, kenyamanan kerja selayaknya menjadi prioritas utama dalam rangka meningkatkan keselamatan kerja, khususnya pada kapal penangkapan ikan yang aktivitasnya berisiko tinggi. Kenyamanan kerja ABK dapat dipengaruhi oleh kondisi ergonomi di kapal. Saat ini, penelitian mengenai ergonomi khususnya kapal penangkapan ikan masih sedikit dilakukan sehingga sejauh mana kenyamanan ABK di atas kapal belum diketahui.

Kapal ikan, alat tangkap ikan dan nelayan merupakan tiga faktor yang mendukung keberhasilan suatu operasi penangkapan ikan. Aktivitas menangkap ikan, terutama di laut merupakan kegiatan yang berisiko tinggi (Grainger,1993). Salah satu jenis kapal yang memiliki aktivitas yang terkonsentrasi di atas dek adalah kapal payang. Ada dua jenis perahu payang, yakni perahu kayu dan perahu fiber (perahu kincang). Perahu payang yang fishing base-nya di PPN Palabuhanratu dan PPI Cibangban hampir semuanya merupakan perahu kayu. Perahu kayu ini berdimensi 10,9×2,65×1 m. Perahu ini menggunakan tenaga penggerak motor tempel bermerk Yamaha 40 PK. Perahu payang tidak memiliki rumah-rumahan (house deck) agar luasan di atas dek cukup luas dan tidak mengganggu proses setting dan hauling payang. Khusus di PPN Palabuhanratu, terdapat pula sedikit kapal kayu bermesin diesel yang menggunakan alat tangkap payang. Pada tahun 2013 hanya tersisa 1 kapal diesel yang mengoperasikan jaring payang. Selain itu, baik di PPN Palabuhanratu maupun PPI Cibangban ada pula sedikit perahu kincang yang menggunakan payang.

Satu perahu payang lazimnya membawa 10 orang yang terdiri dari 1 juru mudi (tekong), satu juru bantu, dan delapan anak buah kapal (ABK). Akan tetapi, pada saat-saat kelimpahan ikan rendah, tidak semua ABK ikut melaut sehingga jumlah nelayan dalam 1 perahu payang kurang dari 10 . Selain itu ada pula beberapa perahu payang yang membawa lebih dari 10 nelayan. Operasi penangkapan ikan, terutama di laut, merupakan kegiatan yang cukup beresiko karena keadaan di laut lepas tidak dapat diprediksi. Kegiatan operasi penangkapan ikan bisa dilakukan di berbagai tipe perairan, mulai dari perairan yang tenang sampai ke perairan yang memiliki gelombang besar seperti di laut lepas (samudera), tergantung pada daerah penangkapan ikan juga sering menimbulkan ketidaknyamanan akibat tata letak atau tempat yang tidak memiliki sinkronisasi terhadap aktivitas yang dilakukan para anak buah kapal (ABK). Ketidaknyamanan tersebut diperkirakan dapat mengakibatkan rendahnya kinerja $\mathrm{ABK}$.

Aktivitas yang terjadi saat pengoperasian kapal payang sering kali berakibat pada kecelakaan yang dialami oleh ABK. Seperti jatuh saat pengoperasian alat tangkap ikan, terbakarnya kapal karena kesalahan operasional mesin, dan tenggelamnya kapal karena kelebihan muatan atau kesalahan saat olah gerak kapal.

Tingkat kecelakaan fatal (meninggal) awak kapal penangkap ikan di dunia, rata rata 80 orang per 100.000 orang awak kapal sehingga meningkatkan perhatian badan international seperti International Maritime Organization (IMO), Food and Agriculture Organization (FAO) dan International Labour Organization (ILO) terhadap pentingnya peningkatan keselamatan dan ketenagakerjaan pada kapal penangkap ikan. Badan-badan dunia tersebut dengan melibatkan pihak tripartite, yakni pemerinta, pemilik kapal dan pelaut perikanan telah mengadopsi suatu konvensi yang berkaitan dengan ketenagakerjaan yang layak (Suwardjo et.al., 2010).

Dengan banyaknya faktor faktor penyebab kecelakaan di kapal payang maka harus dilakukan pengkajian mengenai ergonomi, agar kenyamanan dan penyebab terjadinya kecelakaan bisa diketahui, dengan demikian produktivitas ABK dapat ditingkatkan. Berdasarkan alasan tersebut, 
penelitian tentang ergonomi di kapal payang perlu dilakukan. Harapannya, penelitian ini dapat memberikan rekomendasi untuk meningkatkan kenyamanan kerja di atas kapal (Ahli K3 2015). Tujuan dari penelitian ini adalah menganalisa aspek ergonomi pada aktivitas penangkapan ikan kapal payang.

\section{METODOLOGI PENELITIAN}

Penelitian dilakukan di perairan Palabuhanratu, Sukabumi Jawa Barat pada bulan April 2015. Peralatan yang digunakan dalam penelitian adalah alat ukur, alat tulis, dan kuisioner. Objek penelitian adalah kapal payang beserta ABK-nya. Metode yang digunakan dalam penelitian ini adalah metode observasi langsung pada obyek penelitian. Observasi dilakukan terhadap aktivitas nelayan di atas kapal payang, meliputi tahap persiapan, operasi penangkapan ikan, dan pasca operasi. Metode ini ditunjukan untuk menyelidiki secara terperinci aktivitas, peralatan yang digunakan, cara kerja dan tata letak di atas kapal. Metode ini termasuk dalam metode deskriptif yang digunakan untuk meneliti sekelompok manusia, obyek, kondisi dan suatu sistem pemikiran (Nazir, 1988). Data yang dikumpulkan terdiri dari data primer dan data sekunder. Data primer terdiri atas aktivitas detail di atas kapal, ukuran (panjang, lebar, dalam), cara kerja dan posisi peralatan yang digunakan, pendapat anak buah kapal (ABK) mengenai kenyamanan kerja di atas kapal, kejadian yang mengancam jiwa dalam operasi penangkapan ikan. Sebagai responden adalah para ABK, dan data sekunder yang digunakan dalam penelitian ini berupa general arrangement kapal penangkap payang tersebut, yang diperoleh dari Novita Y. (2014).

Metode pengumpulan data melakukan observasi, wawancara, pengukuran langsung dan dokumentasi pada objek yang diteliti. Menggunakan kuisioner sebagai pedoman wawancara kepada ABK tentang aktivitas di atas kapal, peralatan yang mereka gunakan dan kenyamanan kerja selama operasi penangkapan ikan. Selain itu, data juga diperoleh dengan mengukur dimensi alat dan antrophometri. Dokumentasi dalam bentuk foto dan gambar dikumpulkan untuk memberikan gambaran mengenai kondisi lapang. Sementara itu, general arranggement kapal payang digunakan sebagai alat bantu untuk mempermudah pemetaan tata letak alat dan aktivitas di atas kapal. Rincian metode pengumpulan data, sumber dan jenis data disampaikan pada Tabel 1.

Tabel 1 Metode pengumpulan data, sumber dan jenis data

\begin{tabular}{|c|c|c|c|}
\hline No & Metode & Sumber & Jenis data \\
\hline 1 & Observasi & $\begin{array}{l}\text {-Kapal } \\
\text {-ABK } \\
\text {-Alat } \\
\text {-General arrangement }\end{array}$ & $\begin{array}{l}\text { Data mengenai aktivitas detail, ergonomi dan } \\
\text { informasi tentang kenyamanan kerja dari } A B K\end{array}$ \\
\hline 2 & Wawancara & $-\mathrm{ABK}$ & $\begin{array}{l}\text { Data mengenai aktivitas detail, ergonomi dan } \\
\text { informasi tentang kenyamanan kerja dari } A B K\end{array}$ \\
\hline 3 & $\begin{array}{l}\text { Pengukuran } \\
\text { langsung }\end{array}$ & $\begin{array}{l}\text {-Kapal } \\
\text {-ABK } \\
\text {-Alat }\end{array}$ & $\begin{array}{l}\text {-posisi alat tangkap yang berada di kapal } \\
\text {-posisi dan ukuran alat tangkap terhadap ABK } \\
\text {-dimensi alat tangkap }\end{array}$ \\
\hline 4 & Dokumentasi & $\begin{array}{l}\text {-Kapal } \\
\text {-ABK } \\
\text {-Alat }\end{array}$ & $\begin{array}{l}\text { Gambar atau foto kapal, ABK dan alat yang } \\
\text { diperlukan }\end{array}$ \\
\hline
\end{tabular}

Data yang diperoleh dari lapangan selanjutnya diolah dan dianalisis berdasarkan metode deskriptif analisis kerja dan aktivitas. Pengolahan data dilakukan dengan tabulasi dan pembuatan gambar-gambar yang dibutuhkan untuk analisis ergonomi. Analisis data dilakukan dengan mengkaji jawaban dari responden terhadap pernyataan yang diajukan. Berdasarkan jawaban tersebut, dianalisis 
aktivitas di atas kapal payang. Deskripsi mengenai aktivitas di kapal diperkuat dengan hasil observasi dan dokumentasi.

Data mengenai ergonomi diperoleh dari pengukuran alat tangkap dan aktivitas di atas kapal. Data tersebut dianalisis dengan menbandingkan standard ergonomic yang ada. Berdasarkan pengkajian tersebut, dapat diketahui apakah kapal tersebut sudah memenuhi kaidah ergonomi atau belum. Hasil wawancara juga digunakan untuk menganalisis tingkat kenyamanan ABK. Pada tahap ini dapat diketahui bagaimana tingkat kenyamanan ABK ketika bekerja di atas kapal. Selain itu, sebagai bagian dari analisis keselamatan kerja dilakukan pula analisis keselamatan kerja (job safety analisys / JSA) yang berisikan analisis bagaimana mencegah kecelakaan dengan antisipasi dan eliminasi serta mengontrol bahaya yang ada (Ahli K3 Umum, 2015).

Tahapan penelitian disampaikan pada Gambar 1. Gambar ini merupakan urutan penelitian dari penetapan tujuan sampai dengan penelitian hingga mendapatkan kesimpulan.

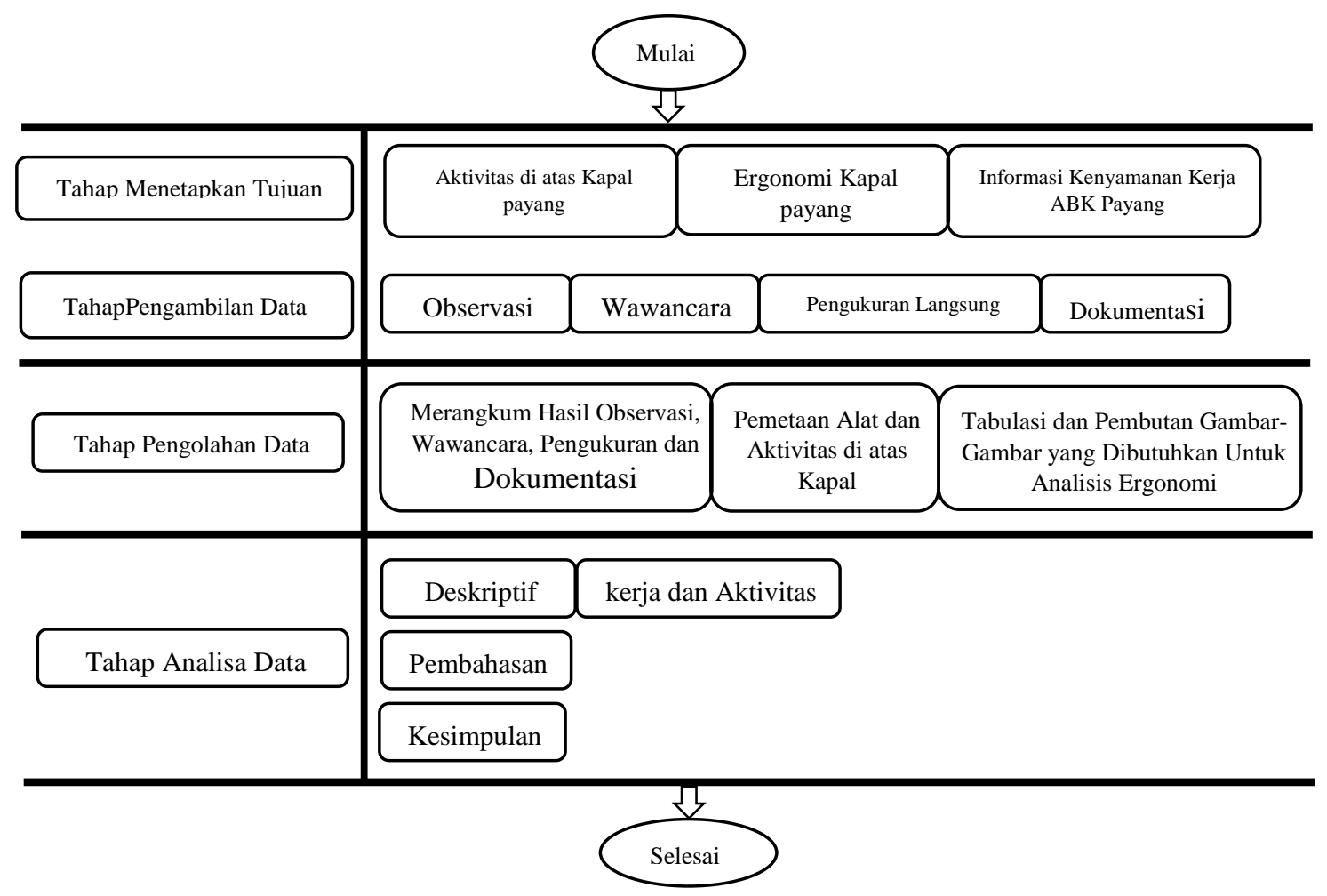

Gambar 1 Tahapan Penelitian

\section{HASIL DAN PEMBAHASAN}

\section{Kondisi Umum Kapal Payang}

Kapal payang ini memiliki area dek untuk kegiatan operasi penangkapan ikan yang tidak begitu luas, hanya setengah dari luas keseluruhan yaitu $5 \mathrm{~m}$ x 1,4 m. Luas area setting kapal payang ini sama dengan luas hauling nya yaitu $5 \mathrm{~m} \mathrm{x} \mathrm{1,4} \mathrm{m.} \mathrm{Kapal} \mathrm{dengan} \mathrm{spesifikasi} \mathrm{seperti} \mathrm{ini} \mathrm{merupakan}$ kapal payang yang umumnya digunakan oleh nelayan di Palabuhanratu Sukabumi.

Berdasarkan bentuk kasko kapalnya yang tergambar pada General Arrangement (Novita Y. 2014), lambung kapal pada bagian haluan berbentuk $V$ bottom. Semakin ke tengah, cenderung membentuk sedikit round bottom dan semakin keburitan membentuk U bottom. Bentuk kasko kapal yang dimiliki kapal jenis ini memungkinkan kapal bergerak bebas dan leluasa untuk melakukan olah gerak saat pengoperasian alat tangkap baik saat melakukan setting maupun hauling. Area yang 
dipakai dalam kapal payang ini terkonsentrasi di atas dek dan relatif sama pada beberapa kapal yang lain. Area yang tersedia di kapal payang ini adalah area kemudi, area setting, area hauling, area untuk penanganan ikan, area penyimpanan bahan bakar, area penyimpanan hasil tangkapan, area untuk menaruh alat tangkap, dan area untuk fishing master yang berada di area yang berbeda dari ABK yang lain. Karena area yang dipakai oleh fishing master berada di atas tiang kapal itu karena dibutuhkan pandangan yang luas untuk melihat keberadaan ikan.

Spesifikasi kapal disampaikan pada Tabel 2 :

Tabel 2 Spesifikasi kapal payang

\begin{tabular}{llll}
\hline No & Spesifikasi & Ukuran & Satuan \\
\hline $\mathbf{1}$ & Panjang (LOA) & 12 & Meter \\
$\mathbf{2}$ & Lebar (B) & 2,8 & Meter \\
$\mathbf{3}$ & Draft (d) & & Meter \\
$\mathbf{4}$ & Kecepatan & 2 & Knot \\
$\mathbf{5}$ & ABK & 10 & Orang \\
$\mathbf{6}$ & Gross tonnage & 5 & GT \\
$\mathbf{7}$ & Mesin (outboard) & 40 & PK \\
$\mathbf{8}$ & Waktu operasi & 12 & Jam \\
\hline
\end{tabular}

Kapal yang berukuran 5 GT ini pola operasinya adalah one day fishing karena hanya melakukan trip selama 14 jam (kurang dari satu hari). Waktu yang dibutuhkan untuk perjalanan menuju fishing ground pertama selama 3 jam. Waktu yang dibutuhkan untuk berpindah ke fishing ground lainnya selama 1 jam. Jumlah setting dan hauling setiap fishing ground tidak pasti, karena ditentukan dengan keberadaan dan ketersediaan ikan dan dibatasi oleh waktu pengoperasian. Kapal berangkat dari fishing base pukul 06.00 menuju fishing ground pertama dengan waktu tempuh 3 jam dan sampai di fising ground pertama pukul 09.00. Setting dan hauling di fishing ground pertama dilakukan operasi penangkapan ikan sampai pukul 12.00 siang. Setelah itu para ABK kapal payang melakukan istirahat sholat dan makan siang selama 1 jam. Selanjutnya melakukan perjalanan 1 jam menuju fishing ground ke dua. Di fishing ground ke dua proses setting dan hauling kembali dilakukan selama 2 jam, kemudian operasi selesai dan bergerak untuk kembali ke fishing base dan tiba pukul 18.00 .

\section{Aktivitas Penangkapan Ikan Kapal Payang}

Operasi penangkapan ikan dibagi menjadi beberapa kegiatan yaitu persiapan, operasi meliputi setting dan hauling, pasca operasi, dan istirahat. Kegiatan tersebut terkonsentrasi di atas dek dan terbagi menjadi beberapa bagian area kerja seperti:

1) Area kemudi sebagai tempat dan juga lokasi juru mudi atau tekong;

2) Buritan sebagai tempat penurunan jaring(setting), tempat penyimpanan blong, tempat menaikkan hasil tangkapan; dan

3) Haluan sebagai tempat penarikan jaring (hauling).

Pembagian tugas pada kapal penangkapan payang disampaikan pada Tabel 3 di bawah ini.

Tabel 3 Pembagian tugas di kapal payang

\begin{tabular}{clcl}
\hline No & Posisi & Jumlah & Tugas \\
\hline 1 & Kapten/ nahkoda & 1 & Mengemudikan kapal \\
2 & Fishing master & 1 & $\begin{array}{l}\text { Melihat posisi ikan dan menentukan olah gerak untuk } \\
\text { setting dan hauling }\end{array}$ \\
& & & Menggiring ikan ke dalam jaring \\
3 & Juru kecrik & 1 & Melempar jaring dan menarik jaring. \\
4 & ABK & 7 &
\end{tabular}




\section{Tahap Persiapan}

Kapten membagi seluruh ABK menjadi dua posisi di buritan dan di haluan, dalam pengerjaan tugas dan keseluruhan kegiatan di kapal kecuali fishing master karena harus tetap berada di puncak kapal dan kapten bertugas mengemudikan kapal. Kegiatan yang dilakukan pada saat persiapan adalah menyiapkan alat yang mencakup:

1) Memindahkan dan mengatur jaring yang semula berada di buritan kapal ke bagian haluan untuk proses setting,

2) Merangkai posisi jaring dan menempatkan di sisi kiri kapal dan

3) Fishing master naik ke puncak kapal untuk mengamati dan menganalisa pergerakan ikan

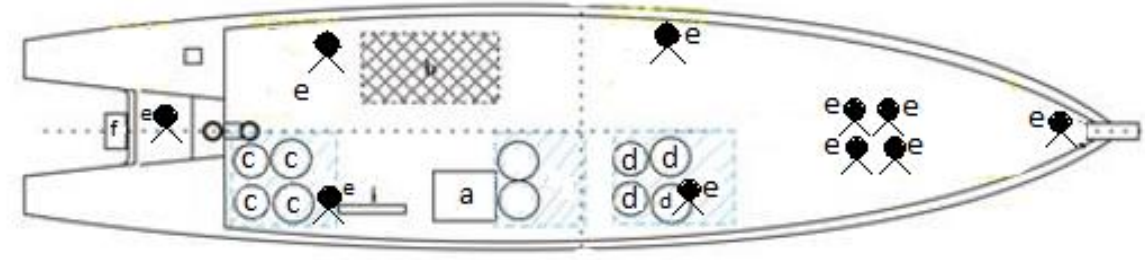

Gambar 2 Posisi persiapan keberangkatan

Keterangan : a: Posisi es batu, b: Posisi jaring, c: Posisi blong/tempat penyimpanan ikan, d: Posisi perbekalan nelayan, e: Posisi ABK, Tekong, Fishing master, f: Posisi mesin/Outboard

Kapten/nahkoda di area kemudi mempersiapkan kapal untuk melakukan olah gerak sesuai arahan dari fishing master. Sementara ABK lain bersiap siap untuk menurunkan jaring dan juru kecrik mengambil posisi di buritan kapal di sisi kiri untuk terjun dan menggiring ikan ke arah jaring dengan menggunakan ban dan alat kecrik.

\section{Tahap Operasi Penangkapan Ikan}

1) Kegiatan setting

ABK berada pada posisi yang sudah diinstruksikan oleh kapten dan sudah disepakati sesuai dengan tugas dan bagiannya. Kapal berada pada kecepatan penuh untuk melakukan olah gerak mengurung ikan atau mengelilingi ikan. Hal ini dilakukan agar saat penurunan jaring bisa dilakukan dalam waktu yang cepat agar gerombolan ikan tidak lari sebelum jaring terbuka sempurna mengitari ikan. Pertama-tama jaring diturunkan dari buritan kapal dan disambut dengan penurunan jaring dari bagian haluan itu dilakukan berbarengan dengan kapal yang berolah gerak membentuk lingkaran, setelah 3 pelampung turun maka juru kecrik juga turun dari buritan dan menjauh dari arah jaring, Hal ini dilakukan untuk menakut-nakuti ikan dengan membuat getaran yang kuat agar ikan lari ke arah jaring.

Setting dilakukan oleh 7 orang, dengan rincian tugas sebagai berikut:

ABK ke-1: menurunkan jaring (buritan); ABK ke-2: menurunkan jaring (buritan);

ABK ke-3: menurunkan jaring (buritan); ABK ke 4: menurunkan jaring (haluan);

ABK ke-5: menurunkan jaring (haluan); ABK ke-6: menurunkan jaring (haluan); dan

ABK ke-7: mengikat tali ris di tiang kapal dan membantu menurunkan jaring.

Juru kecrik: berenang ke sisi jaring yang masih terbuka untuk menggiring ikan masuk ke dalam jaring dan mencegah ikan kabur menjauh dari jaring. 


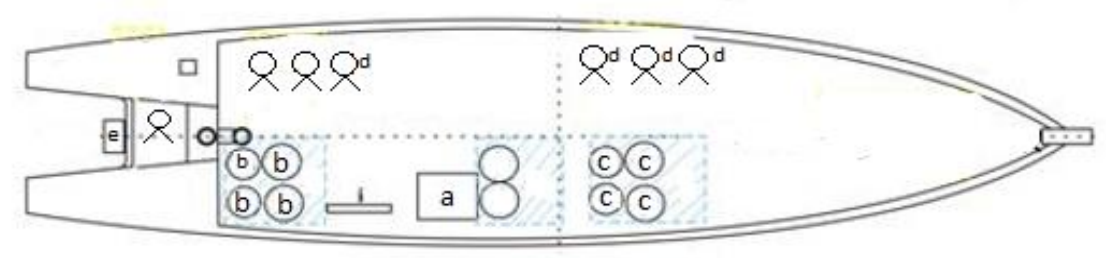

Gambar 3 Posisi setting

Keterangan : a: Posisi es batu, b: Posisi blong/tempat penyimpanan ikan, c: Posisi perbekalan nelayan, d: Posisi ABK, Tekong, Fishing Master

Setelah kegiatan proses setting, ABK tetap dalam posisi semula untuk melakukan proses menaikkan jaring ke atas kapal (hauling). Pada saat proses setting fishing master tetap berada di posisinya semula dan tidak mengikuti kegiatan setting, seluruh kegiatan setting dilakukan di buritan dan haluan kapal.

\section{2) Kegiatan hauling}

Setelah dilakukan proses setting, jaring kemudian ditarik. Proses hauling diawali dengan menaikkan dan mengikat tali ris pada tiang kapal. Kemudian jaring ditarik ke atas kapal dengan ritme yang cepat. Hal ini bertujuan agar ikan yang sudah terkurung dalam lingkaran jaring tidak memiliki kesempatan untuk keluar jaring dari celah pelolosan yang ada. Jaring diangkat dari haluan kapal yang kemudian dilanjutkan dari buritan kapal dan secara bersamaan para ABK menaikkan jaring ke atas kapal sampai keseluruhan jaring berhasil dinaikkan ke atas kapal. Selain itu selama proses penarikan jaring juru kecrik tetap melakukan tugasnya agar ikan tidak dapat melakukan proses menghindari dan menjauh dari jaring hingga setengah jaring dinaikkan keatas kapal juru kecrik baru naik ke atas kapal untuk membantu ABK menaikkan jaring agar proses nya berlangsung lebih cepat.

Kegiatan Hauling dilakukan oleh 7 orang, dengan rincian tugas sebagai berikut:

ABK ke-1 : yang berada diposisi haluan kapal mengambil tali ris lalu diikat

ke tiang kapal, lalu kembali ke posisi untuk membantu menarik jaring ke atas kapal;

ABK ke-2 : menarik jaring untuk dinaikkan ke atas kapal (haluan);

ABK ke-3 : menarik jaring untuk dinaikkan ke atas kapal (haluan);

ABK ke $4 \quad$ : menarik jaring untuk dinaikkan ke atas kapal (haluan);

ABK ke-5 : menarik jaring untuk dinaikkan ke atas kapal (buritan);

ABK ke-6 : menarik jaring untuk dinaikkan ke atas kapal (buritan); dan

Juru kecrik : menyiapkan blong untuk menaruh hasil tangkapan yang sudah dinaikkan ke atas kapal.

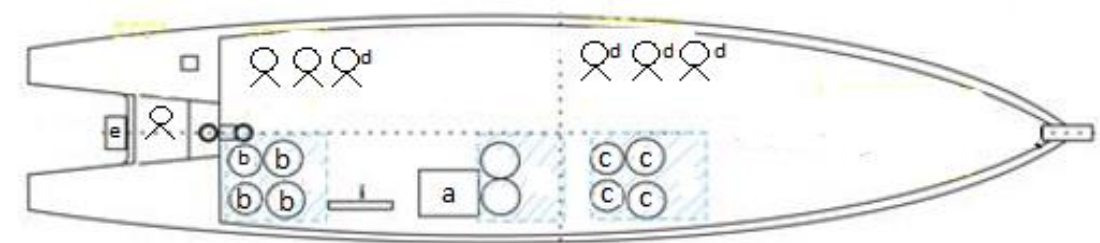

Gambar 4 Posisi saat hauling

Keterangan : a: Posisi es batu, b: Posisi blong/tempat penyimpanan ikan, c: Posisi perbekalan nelayan, d: Posisi ABK, tekong, Fishing Master

Setelah seluruh kegiatan setting dan hauling dilakukan, kegiatan selanjutnya adalah penanganan hasil tangkapan. Penanganan harus langsung dilakukan setelah ikan dinaikkan ke atas kapal. Hal ini sangat menentukan mutu hasil tangkapan. 


\section{Tahap Pasca Operasi Penangkapan Ikan}

Ikan yang tertangkap harus segera ditangani dengan baik dengan cara langsung dimasukan ke dalam blong yang sudah disiapkan yang terlebih dahulu diisi es batu. Hal ini dilakukan agar ikan tidak terlalu lama terkena sinar matahari, karena dapat merusak mutu ikan. Hasil tangkapan payang tidak diperlukan proses pembunuhan ikan dan pengambilan organ dalam ikan karena ikan langsung dimasukan ke dalam blong yang sudah berisi es batu.

\section{Tahap Istirahat}

Setelah keseluruhan rangkaian kegiatan operasi penangkapan ikan yang dimulai dari persiapan, operasi dan pasca operasi, seluruh ABK diberikan waktu istirahat. Waktu istirahat ini dapat digunakan untuk memulihkan tenaga setelah melakukan hauling. Area istirahat tersebut tidak tersedia khusus di atas kapal, para ABK beristirahat ditempat semula mereka melakukan proses setting dan hauling, luas area kerja yang sempit.

Waktu untuk istirahat sudah cukup untuk memulihkan tenaga dalam satu jam. Selesai melakukan proses penangkapan ikan di tempat pertama mereka bisa beristirahat dengan waktu yang lebih lama tergantung dengan hasil tangkapan. Jika hasil tangkapan sedang banyak, bahkan mereka tidak melanjutkan proses operasi penangkapan pada fishing ground yang kedua, mereka langsung kembali ke fishing base untuk mendaratkan hasil tangkapannya.

\section{Aspek Ergonomi pada Aktivitas Penangkapan Ikan}

Kajian ergonomi menekankan pada pengkajian desain kapal (khususnya General Arrangement/GA) dan alat bantu yang disesuaikan dengan aktivitas yang terjadi di atas kapal. Penerapan ergonomi di atas kapal dapat menunjukkan tercapainya kenyamanan dalam bekerja sehingga tercipta suasana yang mendukung produktivitas operasi penangkapan ikan. Pihak pihak yang terlibat dalam aplikasi ergonomi di atas kapal adalah :

1) Pengrajin kapal, bertanggung jawab dalam pembuatan konstruksi kapal dan peralatan bantunya. Kualitas yang baik bertujuan untuk menjamin kapal berfungsi baik selama operasi penangkapan. Pembuatan kapal yang memiliki kualitas baik juga ditujukan untuk terciptanya sebuah kapal penangkap ikan yang dapat melakukan usaha penangkapan yang produktif. Kapal yang ada di Palabuhanratu belum memenuhi kaidah ergonomi karena alat bantu tidak memadai untuk kegiatan operasional, salah satu contohnya tidak adanya kursi untuk tekong / pengemudi kapal.

2) Pemilik kapal, bertanggung jawab pada keamanan ABK dan perawatan kapal dan peralatan bantunya. Selain itu, perlu juga memperhatikan kebutuhan ABK dalam operasional untuk mendapatkan produktivitas maksimal yang merupakan tujuan utama dari operasi penangkapan ikan. Kapal yang ada di Palabuhan ratu belum cukup terawat, karena dilihat dari kondisi kapal yang sudah miring saat olah gerak kapal, dan banyaknya tritip yang menempel pada kasko kapal.

3) Anak buah kapal (ABK), operasi penangkapan ikan diharapkan dapat berjalan dengan baik. Operasi yang berjalan dengan baik dan aman menjadi harapan bagi seluruh ABK. ABK juga harus melakukan pemeliharaan peralatan dengan baik agar selalu siap digunakan. ABK diharapkan dapat memberikan masukan kepada pemilik kapal untuk meningkatkan kenyamanan kerja.

Berikut ini akan dijabarkan kajian ergonomi kapal payang berdasarkan pembagian areanya. Kajian ergonomi tersebut disesuaikan dengan kajian aktivitas dan alat bantu yang digunakan. Pembagian area untuk area kerja kajian ergonomi ini dibagi menjadi: area kemudi, area setting dan area hauling. Area setting dan hauling digabungkan dalam penjabarannya karena kedua proses ini dilakukan pada area yang sama. 


\section{Area Kemudi}

Sebelum melakukan operasi penangkapan ikan dibutuhkan beberapa persiapan. Persiapan tersebut ditujukan untuk memaksimalkan kegiatan operasi penangkapan ikan. Kerjasama pekerja dan lingkungan pekerja dalam persiapan dapat meningkatkan kepuasan kerja. Salah satu persiapan dalam operasi penangkapan ikan menggunakan kapal payang adalah persiapan keluar dari dermaga dan menuju daerah penangkapan ikan. Berikut dijabarkan aplikasi dari ergonomi yang diterapkan dalam persiapan yang meliputi posisi kerja dan tata letak tempat kerja.

Persiapan lepas tambat dari dermaga dilakukan oleh kapten dari area kemudi dengan luas area 1 x 1 meter. Area kemudi tidak terdapat alat bantu yang mencukupi, karena hanya menggunakan mesin tempel dan propeller yang langsung dikemudikan oleh kapten, sehingga keberhasilan keluar dari dermaga tanpa mengalami kerusakan ditentukan oleh kemahiran dan pengalaman kapten, dibantu dengan para ABK.

Posisi tekong/kapten kapal saat mengemudikan kapal berada pada bagian buritan kapal. Tidak ada area dan fasilitas khusus untuk tekong mengendalikan kapal. Tekong hanya duduk di dek kapal dengan tangan dibelakang mengendalikan mesin. Hal ini jelas tidak ergonomi karena duduk lama terutama lebih dari 4 jam dan sikap duduk yang salah seperti mumbungkuk dapat menyebabkan nyeri punggung belakang (NPB). Bila keadaan ini dibiarkan berlanjut dapat mengakibatkan gangguan pada diskus intervertebralis yang menyebabkan performa tekong menurun karena dilakukan berulangulang (Samara D, 2004).

Orang-orang yang harus duduk untuk jangka waktu yang lama, seharusnya duduk di atas kursi dengan alas dan sandaran keras. Alas dan sandaran yang ideal membentuk sudut $100^{\circ}-110^{\circ}$. Tinggi alas harus sedemikian rupa sehingga orang dapat duduk dengan fleksi sempurna baik pada sendi lutut dan panggul, sedangkan kaki tepat mendatar di atas lantai. Jok mobil dan sofa merupakan tempat duduk yang ideal namun untuk jangka waktu lama akan menimbulkan nyeri akibat regangan otototot hamstring dan ligamentum longitudinale posterior (Juadana A, 1981).

Oleh karena itu terdapat beberapa hal yang harus dilakukan selama duduk, yaitu sebaiknya duduk dengan punggung lurus dan bahu berada di belakang dengan bokong menyentuh belakang kursi. Gulungan handuk kecil dapat digunakan untuk mempertahankan kurva tulang belakang . Apabila tidak terdapat pendukung lumbal, dapat dilakukan dengan cara duduk di ujung kursi dan membungkuk sempurna. Tubuh ditegakkan dan lengkungan tubuh (kurva) dibuat sebisa mungkin, kemudian tahan beberapa detik. Setelah itu posisi tersebut dilepaskan secara ringan (sekitar 10 derajat). Keadaan ini merupakan posisi tubuh terbaik (Cleveland Clinic Spine, 2015).

\section{Area Istirahat}

Operasi penangkapan ikan yang dilakukan para ABK KM Pemuda akan menimbulkan kelelahan. Kelelahan dalam operasi penangkapan ikan diminimalkan dengan penerapan istirahat pendek dan istirahat aktif. Demikian dapat disimpulkan bahwa operasi penangkapan ikan dapat meningkatkan efisiensi waktu kerja serta mengurangi kelelahan ABK, namun sangat disayangkan fasilitas yang tersedia di atas kapal untuk para ABK kurang memadai, karena KM Pemuda tidak dilengkapi dengan area istirahat yang khusus. Mereka hanya bisa beristirahat di tempat mereka melakukan operasi penangkapan ikan. Hal ini disebabkan karena luas kapal yang berukuran kecil.

\section{Area Setting dan Hauling}

Setting dan hauling dilakukan di bagian kapal yang sama, yaitu di bagian buritan dan haluan. Kegiatan ini melibatkan seluruh ABK. Setting dilakukan setelah seluruh persiapan dilakukan, yaitu persiapan posisi jaring dan posisi ABK. Selain itu hal yang penting sebelum setting adalah setelah fishing master sudah bisa menganalisa keberadaan ikan dan pergerakan ikan. Hasil dari analisis 
fishing master ini digunakan untuk menentukan teknik setting yang tepat. Setelah melakukan setting para ABK harus kembali bersiap melakukan hauling.

Hauling dilakukan setelah proses setting dilakukan dan juru kecrik sudah kembali ke atas kapal. Posisi ABK saat proses hauling sama dengan posisi saat setting. Proses setting dan hauling menggunakan payang harus berlangsung dengan waktu yang singkat agar bisa memaksimalkan jumlah hasil tangkapan.

Operasional penangkapan ikan yang meliputi setting dan hauling pada kapal payang dilakukan tanpa alat bantu mesin. Kegiatan dilakukan dengan tenaga manusia yang menyebabkan ABK mengalami kelahan fisik. Aktivitas sehari-hari yang menuntut banyak gerak ke depan maupun membungkuk di banding ke belakang, duduk, berdiri terlalu lama atau postur batang tubuh lainnya yang janggal akan mengakibatkan nyeri pinggang non spesifik (Harianto, 2010).

\section{Aspek Keselamatan Kerja ABK di Atas Kapal}

Masalah keselamatan kapal dan nelayan merupakan hal yang menjadi perhatian dunia. Telah banyak kebijakan-kebijakan international yang berkenaan dengan keselamatan di laut. Menurut IMO, 80\% dari kecelakaan disebabkan oleh kesalahan manusia (human error) dan sebagian besar kesalahan ini dapat dihubungkan dengan kekurangan dalam manajemen yang menciptakan praproduksi untuk terjadinya kecelakaan (Blanc M., 2006).

Standar keselamatan international untuk kapal-kapal nelayan yang sudah ada adalah Protocol Torremolinos 1993, Code of Safety for Fishermen and Fishing Vessels / Panduan Keselamatan untuk Nelayan dan Kapal Perikanan FAO/IMO 2005, dan Voluntary Guidelines for The Design, Construction and Equipment of Small Fishing Vessels / Pedoman Sukarela untuk Konstruksi, Desain dan Peralatan Kapal Perikanan Ukuran Kecil [FAO] 2006, [ILO] 2006.

Pedoman/petunjuk keselamatan kerja nelayan dan kapal ikan yang dikeluarkan oleh [IMO] 1980 pada Voluntary Guidelines for The Design,Consrtruction, and Small Fishing ini diperuntukan pada kapal dengan ukuran panjang di atas 12 meter sampai dengan lebih kecil dari 24 meter. Kedua pedoman ini merupakan produk bersama antara IMO, ILO dan FAO.

Standar international yang berkaitan dengan keselamatan kerja nelayan adalah Standar Pelatihan, Sertifikasi dan Watchkeeping for Fishing Vessels Personnel(STCW-F) 1995, dan Dokumen mengenai Pedoman Pelatihan dan Sertifikasi awak Kapal Perikanan/Document for Guidance in Training and Certification of Fishing Vessels Personnel FAO/ILO/IMO 2001. STCW-F 1995 ini antara lain berisi tentang sertifikasi dan pengaturan serta pengesahannya, dasar pelatihan keselamatan bagi semua awak kapal penangkap ikan, prosedur pengawasan, komunikasi informasi, dan pedoman lainnya bagi nelayan dan kapal penangkapan ikan. Tujuan ditetapkannya SCTW-F 1995 adalah untuk memperkecil tingkat kecelakaan dan pencemaran di laut, serta meningkatkan SDM pelaut perikanan yang berstandar international.

Konvensi dan rekomendasi ILO yang berhubungan secara khusus dengan sektor perikanan meliputi jam kerja (perikanan)/Hours of Work (Fishing) Recomendation, 1920 (no 7), Konvensi Usia Minimum (Nelayan)/Minimum Age (Fishermen) Convention, 1995 (No 112), Konvensi Pemeriksaan Kesehatan/Medical Convention Examination (Fishermen) Convention.1959 (No 113), Konvention sertifikat Kompettensi Nelayan/Fishermen Competency Certificates Convention, 1996 (No 125).

Rekomendasi Jam Kerja (Perikanan)/Hours of Work (Fishing) Recomendation, 1920 (No 7) diselenggarakan di Genoa oleh Badan Pimpinan Kantor Perburuhan International pada 15 Juni 1920 dan diputuskan untuk mengadopsi usulan-usulan tertentu untuk diterapkan pada konvensi pelaut yang disusun di Washington, yang berisi mengenai batas jam kerja pada semua usaha industri, termasuk transportasi laut dan, dalam kondisi yang ditentukan, transportasi melalui lintas air, sampai dengan 8(delapan) jam dalam sehari. Setelah menetapkan usulan-usulan ini akan dibentuk sebuah 
Rekomendasi, yang dapat disebut sebagai Rekomendasi Jam Kerja (perikanan), 1920. Minimum Age (Fishermen) Convention Nomor 112 tahun 1959, adalah konvensi yang menetapkan bahwa anakanak yang berusia dibawah 15 tahun tidak dipekerjakan pada kapal-kalap nelayan. Konvensi ini juga menetapkan bahwa anak-anak boleh mengambil bagian dalam kegiatan penangkapan ikan selama liburan, selama sesuai dengan kondisi-kondisi tertentu, yaitu kegiatan tidaklah berbahaya bagi kesehatan mereka, atau pendidikan/perkembangan normal mereka, seperti tidak merugikan kehadiran sekolah, dan tidak ada niatan untuk tujuan komersil. Konvensi ini telah diberlakukan pada tanggal 7 november 1961 dan menurut data ILO sampai tahun 2000 diketahui 29 negara telah meratifikasinya.

Medical Examination (Fisherman) Convention Nomor 113 tahun 1959, merupakan kinvensi yang secara umum menetapkan bahwa setiap orang yang bekerja pada kapal-kapal nelayan harus memiliki suatu sertifikat kesehatan badan ditandatangani oleh bagian kesehatan yang ditunjuk dan di setujui oleh pemerintah setempat yang berwenang. Konvensi ini diberlakukan pada tanggal 7 november 1961, dan menurut ILO sampai tahun 2000 diketahui 29 negara anggota telah meratifikasinya.

Saat ini, tidak ada standar international keselamatan di kapal yang berlaku bagi kapal penangkap ikan berukuran panjang kurang dari $12 \mathrm{~m}$ yang memiliki dek dan kapal penangkap ikan tanpa dek dari berbagai ukuran. Standar perlu dikembangkan, karena sebagian besar kematian terjadi di atas kapal nelayan pada ukuran tersebut. Pada bulan Desenber 2004, Komite Keselamatan Maritim IMO (MSC) sepakat untuk memasukan dalam program kerja-sub Komite tentang Stabilitas dan batas muat Keselamatan Kapal Perikanan dengan prioritas utama berhubungan dengan 'Keselamatan Kapal Nelayan berukuran kecil', yang dijadwalkan selesai tahun 2009. FAO bermaksud untuk berpartisipasi aktif dalam pengembangan standar-standar baru ini (Purwangka F. et al, 2013).

Keselamatan kerja ABK Kapal payang dilakukan dengan pendekatan analisis keselamatan kerja I Job Safety Analysis (JSA). JSA dikenal juga dengan job hazard analysis merupakan upaya untuk mempelajari/menganalisa dan serta pencatatan tiap-tiap urutan lengkah kerja suatu pekerjaan. Dilanjutkan dengan identifikasi potensi-potensi bahaya didalamnya, kemudian diselesaikan dengan menentukan upaya terbaik untuk mengurangi ataupun menghilangkan/mengendalikan bahayabahaya pada pekerjaan yang dianalisis tersebut (Ahli K3 Umum, 2015).

Dengan menyusun/menerbitkan dan mensosialisasikan JSA pada tenaga kerja merupakan salah satu upaya untuk mencegah terjadinya kecelakaan kerja di tempat kerja(Ahli K3 Umum 2015).

Langkah langkah dalam menyusun JSA antara lain;

1) Menentukan jenis pekerjaan

Pekerjaan yang memiliki riwayat kecelakaan kerja paling parah ataupun sering merupakan prioritas utama untuk dianalisa keselamatannya. Faktor-faktor yang perlu diperhatikan dalam menentukan pekerjaan yang akan dianalisa adalah sebagai berikut ;

- Tingkat keseringan kecelakaan kerja;

- Tingkat kecelakaan yang menyebabkan cacat;

- Potensi kecelakaan kerja;

- Pekerjaan yang bersifat baru;

- Pekerjaan yang memiliki riwayat hamper celaka (nearmis)

2) Merinci urutan-urutan / langkah langkah pekerjaan dari awal dimulai pekerjaan sampai dengan selesainya pekerjaan.

3) Mengidentifikasi bahaya dan potensi kecelakaan kerja terhadap tiap tiap urutan kerja yang dilakukan.

4) Menentukan langkah pengendalian terhadap bahaya-bahaya tiap urutan kerja yang dilakukan.

Setiap melakukan kegiatan ataupun pekerjaan selalu ada risikonya. Risiko kegiatan penangkapan ikan sangatlah tinggi karena medan yang sangat berbahaya, yaitu di laut yang sangat 
tidak dapat diprediksi keadaannya. JSA dilakukan untuk meningkatkan kenyamanan dalam bekerja di atas kapal. Jenis bahaya berikut harus dipertimbangkan ketika menyelesaikan JSA agar dapat dilakukan tindakan untuk mengurangi risiko/bahaya:

1) Dampak dari barang jatuh/terbang.

Blong, ember maupun pelampung yang diletakkan di tempat yang tidak stabil atau licin sangat memungkinkan benda tersebut berpindah tempat atau bergeser bahkan jatuh. Jatuhnya benda tersebut disebabkan oleh posisinya yang kurang stabil, untuk itu perlu dilakukan pengikatan untuk membuat benda tidak terlalu banyak bergerak yang kemudian dapat menimbulkan bahaya.

2) Tusukan benda tajam.

Tusukan seperti pisau untuk penanganan, ganco dapat melukai tangan ABK. Ketidak hati-hatian yang mengakibatkan bahaya ini terjadi. Risiko dapat dikurangi dengan menggunakan wear pack dan pelindung tangan seperti sarung tangan berbahan plastik maupun wool. Wear pack dan sarung tangan tidak digunakan dalam operasi penangkapan ikan ini karena mereka merasa tidak perlu.

3) Jatuh atau terpeleset dari dek kapal.

Kondisi kapal sangat mudah basah oleh air hujan maupun air laut. Hal ini dapat menyebabkan tumbuhnya jamur. Jamur yang tumbuh memiliki lendir yang dapat membuat ABK terpeleset dan dapat pula menimbulkan infeksi. Pengurangan risiko terpeleset dilakukan dengan membersihkan tangga/dek dan berhati-hati dalam melangkah. Selain itu dapat digunakan sepatu boot dengan sol yang kasar.

4) Mengangkat mendorong, menarik, atau meraih berlebihan.

Pelampung tanda, blong, ember, pelampung maupun hasil tangkapan merupakan beberapa benda yang paling sering dipindah tempatkan. Pemindahan alat bantu tersebut masih dilakukan dengan cara manual. Beban yang berat seringkali menimbulkan risiko kecelakaan maupun kesehatan seperti terjatuh, terkilir dan keseleo. Tidak ada alat bantu untuk mengangkat bendabenda berat tersebut.

5) Gerakan berulang

Gerakan yang dilakukan berulang dapat menimbulkan bahaya kesehatan. Kegiatan tersebut antara lain menurunkan dan menaikkan jaring saat kegiatan operasi penangkapan ikan. Mengeluarkan air yang masuk ke dalam kapal. Alat bantu seperti line hauler dan pompa pembuangan air sangat diperlukan di kapal ini. Harga alat yang tinggi membuat pemilik mengurungkan niat untuk menggunakan alat bantu tersebut.

6) Kemungkinan untuk tenggelam.

Kemungkinan untuk tenggelam setiap kapal pasti ada. Kemungkinan ini dapat dihindari dengan memberikan pelatihan yang matang kepada kapten dalam melakukan olah gerak dan berusaha bertahan dalam kondisi cuaca buruk. Namun, kapten hanya mengandalkan pengalaman dalam melaut. Pelatihan tersebut pastinya juga akan membutuhkan biaya yang tidak sedikit, sehingga kapten lebih memilih mengandalkan pengalamannya saja. Pemilik tidak menyediakan life jacket untuk keamanan. ABK juga tidak terlalu mempedulikan dengan hal itu karena mereka cenderung pasrah kalau ada kecelakaan yang terjadi.

\section{Tingkat Kenyamanan ABK}

Informasi tingkat kenyamanan dapat diperoleh melalui wawancara dan pengamatan langsung. Penilaian tingkat kenyamanan sangat bersifat subjektif. Seluruh ABK atau $100 \%$ dari jumlah ABK sudah merasa nyaman karena mereka mengakui bahwa sudah merasa terbiasa dengan kondisi tersebut. Perbaikan oleh pihak pemilik kapal diharapkan untuk meningkatkan kenyamanan kerja yang nantinya akan berpengaruh pada produktivitas ABK. Namun demikian, dari sudut pandang ergonomis beberapa aktivitas tidak, bahkan jauh dari ergonomis seperti: 
1) Area kemudi, kursi yang teralu tinggi dan sempit yang terbuat dari kayu dapat mengakibatkan paha tertekan, peredaran darah lambat, melemahnya stabilitas tubuh dan terjatuh atau terjungkal dari kursi. Harus disediakan GPS yang berada di atas ruang kemudi

2) Area istirahat $\mathrm{ABK}$, harusnya disediakan tempat khusus atau disediakan bantalan empuk untuk para $A B K$ beristirahat dan terpal untuk menahan teriknya sinar matahari agar ABK bisa memulihkan tenaganya kembali.

3) Setting dilakukan dengan cara manual oleh ABK. Cara membungkuk dan tegak yang dilakukan berulang dan tidak sesuai dengan aturan yaitu jongkok dan mengambil alat yang diperlukan dapat mengakibatkan sakit pada pinggang dan lutut. Alat bantu seperti katrol hidrolik dibutuhkan untuk ukuran jaring yang lebih besar.

4) Hauling dilakukan tanpa menggunakan alat bantu dan dilakukan dengan cara manual oleh para ABK. Bahaya yang ditimbulkan dari proses ini sama seperti setting, bahkan bisa kehabisan tenaga karena mengeluarkan banyak tenaga saat menarik jaring. Alat bantu seperti katrol hidrolik dibutuhkan untuk ukuran jaring yang lebih besar.

\section{KESIMPULAN}

Dari sudut pandang ergonomi, desain peralatan dan alat bantu di atas kapal payang belum termasuk kedalam kategori ergonomi, karena desain peralatan dan alat bantu yang belum sesuai dengan kaidah ergonomi seperti belum tersedianya: kursi kemudi di area kemudi; alat navigasi di area kemudi; area istirahat ABK yang layak dan memberikan kenyamanan; alat keselamatan. Pasa saat Setting dan Hauling masih dioperasikan dengan cara manual; ABK yang bertugas pada penanganan hasil tangkap tidak dilengkapi alat bantu.

\section{DAFTAR PUSTAKA}

[FAO] 2006 Food Agriculture Organization. 2006. Code of Safety for Fishermen and Fishing Vessels 2005. Part B. Safety and Healty Requirements for The Construction and Equipment of Fishing Vessels. London.

[ILO] 2006 International Labor Organization, [FAO] Food Agriculture Organization. 2006. Code of Safety for Fishermen anf Fishing Vessels 2005. Part A. Safety and Health Practice. London.

[IMO] 1980 International Maritime Organization. 1980. Voluntary Guidance for The Design, Construction and Equipment of Small Fishing Vessels. London.

Ahli Umum K3. 2015. Job Safety Analysis (JSA) .http://Sistem manajemen Kerja.Blogspot.com [13 Oktober 2015].

Antara. 2009. Pemerintah Mesti Memperhatikan Nasib Nelayan Traditional. Bali Post. Senin, 23 Maret 2009. Hal 17 Kolom 5.

Artayasa I N. 2010. Ergonomi dengan Pendekatan Menyeluruh dari Awal Sampai Kini. Bali: Fakultas Kedokteran, Universitas Udayana.

Blance M. 2006. Tools for Improved Fishing Vessels Safety : The Torremolinos Protocol and The STCW-F .hal 116-January/ March 2006. SPC Fisheries Newsletter. Nearshore Fisheries Development and Training Adviser, Secretariat of The Pacific Community. P 30-32.

Cleveland Clinic Spine Center. 2015. Posture for Healty Back. Available From URL: http// www.clevelandclinic.org. Accessed Okt 19, 2015.

Grainger,
http://www.who.int/iris/handle/10665/49137 of $\quad$ commercial $\quad$ fishing/C.R. $\quad$ Grainger.

Harianto R. 2010. Buku Ajar Kesehatan Kerja:EGC 
Judana A. Low Back Pain: Beberapa Segi Klinik dan Peatalaksanaan. Neurona. 1982 : 2 : 40-43

Purwangka F., Sugeng H. W., Budhi H. I., John H., (2013). Kebijakan Internasional Mengenai Keselamatan Nelayan.BuletinPSP Vol 21, No 12013

Nasir M. (1988) Metode Penelitian, Ghalia Indonesia, Jakarta 1988

Novita Y. 2014. Quality of Payang Boat and Stability. IPTEKS Journal Hal: 28-39.

Samara D. 2004. Lama dan sikap Duduk Sebagai Faktor Risiko Terjadinya Nyeri Pinggang Bawah. Jurnal Anatomi Fakultas Kedokteran Universitas Trisakti. April-Juni 2004,Vol.23 no.2.

Suwardjo D., John H., Indra J., Soen'an P.H. (2010). Kajian Tingkat Kecelakaan Fatal, Pencegahan dan Mitigasi Kecelakaan Kapal Penangkap Ikan Yang Berbasis Operasi Di PPP Tegalsari, PPN Pekalongan Dan PPS Cilacap. Jurnal Teknologi Kelautan dan Perikanan, Volume 10 No.1- Maret 2010. 